\title{
Estimating renal impairment and evaluating antiretroviral dose adjustments among HIV-positive patients: a comparison of three hospitals
}

\author{
K Mackie $^{1}$, R Weston ${ }^{2}$, S Sonecha*3, A Murungi ${ }^{3}$ and A Duncan ${ }^{4}$
}

Address: ${ }^{1}$ Alfred Hospital, Melbourne, Australia, ${ }^{2}$ Imperial College Healthcare NHS Trust, London, UK, ${ }^{3}$ Chelsea and Westminster NHS Foundation Trust, London, UK and ${ }^{4}$ Alfred Hospital, Melbourne, UK

* Corresponding author

from Ninth International Congress on Drug Therapy in HIV Infection

Glasgow, UK. 9-13 November 2008

Published: 10 November 2008

Journal of the International AIDS Society 2008, I I (SuppI I):P204 doi:I0.I I86/I758-2652-I I-SI-P204

This abstract is available from: http://www.jiasociety.org/content/I I/SI/P204

(C) 2008 Mackie et al; licensee BioMed Central Ltd.

\section{Purpose of the study}

As HIV-positive patients are now surviving longer, they are exposed to an increasing number of risk factors for chronic renal failure (CRF) including HIV itself, aging and co-morbidities such as hypertension, diabetes and vascular disease. This necessitates an increased awareness of potential CRF by both HIV clinicians and pharmacists $[1,2]$.

The purpose of this study was to estimate prevalence of renal impairment in a randomly selected group of HIVinfected patients at three hospital outpatient clinics (one Melbourne, two London) and to analyse antiretroviral (ARV) dosing in those patients found to have renal impairment; by comparing published dosing recommendations with actual dosing.

\section{Methods}

Patients were selected randomly from outpatient ARV prescriptions dispensed in pharmacy. Two serum creatinine samples taken at least 6 months apart were reviewed for each patient. Creatinine clearance $(\mathrm{CrCl})$ was estimated firstly using the Modification of Diet in Renal Disease formula (eGFR). Patients with an eGFR of $<60 \mathrm{~mL} / \mathrm{min}$ were reviewed further by estimating $\mathrm{CrCl}$ using the CockcroftGault (CG) formula. Patients with both CG $\mathrm{CrCl}$ measurements $<50 \mathrm{~mL} / \mathrm{min}$, which may require ARV dosage adjustment, were checked against pharmacy dispensing records to see if the appropriate dose had been prescribed.

\section{Summary of results}

Patient cohorts included Alfred Hospital $(n=200)$, St Mary's Hospital $(\mathrm{n}=225)$ and Chelsea \& Westminster Hospital $(\mathrm{C} \& \mathrm{~W}, \mathrm{n}=197)$. Total number of patients included was 622. Results showed that overall 21 (3.4\%) and $19(3.1 \%)$ patients had a $\mathrm{CrCl}$ of $<60 \mathrm{~mL} / \mathrm{min}$ using eGFR and CG, respectively. Dosage adjustments were required in 13 patients, but were only made in five patients. Antiretrovirals concerned included lamivudine, emtricitabine and tenofovir. Of the eight patients who failed to have dosage adjustments made, seven were taking a combination product, either Truvada ${ }^{\circledR}$ or Kivexa ${ }^{\circledR}$. Some patients were on more than one ARV drug requiring dose adjustment. (Tables 1 and 2.)

\section{Conclusion}

Although eGFR is now clinically regarded as the new standard for measuring renal impairment, dose adjustment recommendations for ARV drugs are based on CG estimates. With the introduction of fixed dose combina-

Table I: Patient demographics.

\begin{tabular}{llll}
\hline & Alfred & St Marys & C\&W \\
\hline Number of patients & 200 & 225 & 197 \\
Median age in years (range) & $46(22-81)$ & $42(17-76)$ & $45(18-76)$ \\
Male (\%) & $184(92)$ & $175(78)$ & $173(88)$ \\
Race: non-Black (\%) & $196(98)$ & $154(68.4)$ & $169(85.8)$
\end{tabular}


Table 2: Results.

\begin{tabular}{|c|c|c|c|c|}
\hline & Alfred & St Marys & C\&W & Overall \\
\hline Number of patients & 200 & 225 & 197 & 622 \\
\hline eGFR $<60 \mathrm{~mL} / \mathrm{min} / \mathrm{l} .73 \mathrm{~m} 2$ & $7(3.5 \%)$ & $6(2.7 \%)$ & $8(4.1 \%)$ & $21(3.4 \%)$ \\
\hline$C G<60 \mathrm{~mL} / \mathrm{min}$ & $5(2.5 \%)$ & $6(2.7 \%)$ & $8(4.1 \%)$ & $19(3.1 \%)$ \\
\hline $\mathrm{CG}<50 \mathrm{~mL} / \mathrm{min}$ requires $\mathrm{ARV}$ dose adjustment & $5(2.5 \%)$ & $3(1.3 \%)$ & $5(2.5 \%)$ & $13(2.1 \%)$ \\
\hline Number of patients prescribed correct adjusted ARV dose if required & $3(60 \%)$ & I (33\%) & I (20\%) & $5(38 \%)$ \\
\hline No. of patients on lamivudine requiring dose adjustment & 5 ( 2 adjusted) & I ( 0 adjusted $)$ & 3 (0 adjusted $)$ & 9 ( 2 adjusted) \\
\hline No. of patients on emtricitabine requiring dose adjustment & 0 & I ( 0 adjusted $)$ & 2 (I adjusted) & 3 (I adjusted) \\
\hline No. of patients on tenofovir requiring dose adjustment & 2 (2 adjusted) & 2 (I adjusted) & 2 (I adjusted) & 6 (4 adjusted) \\
\hline
\end{tabular}

tions, pharmacists should be aware that drug dose adjustment may require use of individual drugs and liquid formulations. Further work needs to be undertaken in individual units to develop a system for identifying patients who require careful renal monitoring and subsequent dosage adjustment. The result of not adjusting doses when required needs to be studied.

\section{References}

I. Mocroft A, et al.: Chronic renal failure among HIV-I infected patients. AIDS 2007, 2 I: I I 19-1 I 27.

2. Bagnis $\mathrm{Cl}$, Deray G: Renal consequences of HIV and HIV therapy. Current Opinions in HIV and AIDS 2007, 2:314-317.
Publish with Biomed Central and every scientist can read your work free of charge

"BioMed Central will be the most significant development for disseminating the results of biomedical research in our lifetime."

Sir Paul Nurse, Cancer Research UK

Your research papers will be:

- available free of charge to the entire biomedical community

- peer reviewed and published immediately upon acceptance

- cited in PubMed and archived on PubMed Central

- yours - you keep the copyright

Submit your manuscript here:

http://www.biomedcentral.com/info/publishing_adv.asp 